Bangladesh J. Plant Taxon. 27(1): 1-14, 2020 (June)

(C) 2020 Bangladesh Association of Plant Taxonomists

\title{
LEAF ARCHITECTURE AND PETIOLE ANATOMY OF PHILIPPINE DIPTEROCARPUS SPECIES (DIPTEROCARPACEAE)
}

\author{
Jonathan O. Hernandez ${ }^{1}$, Lerma S.J. Maldia, Dennis E. Pulan ${ }^{2}$, \\ INOCENCIO E. BUOT JR. ${ }^{3}$ AND BYUNG BAE PARK ${ }^{1} *$ \\ Department of Forest Biological Sciences, College of Forestry and Natural Resources, \\ University of the Philippines Los Baños, College 4031, Laguna, Philippines
}

Keywords: Dipterocarpus; Leaf architecture; Petiole anatomy; Taxonomic markers

\begin{abstract}
The study investigated the leaf architecture and petiole anatomy of eight Dipterocarpus (Dipterocarpaceae) species growing in Mount Makiling Forest Reserve (MMFR) in the Philippines to delineate the species, especially during their non-flowering phase. Leaf and petiole samples from MMFR were examined following the manual on leaf architecture studies. Freehand technique was used to examine the stomata and petiole characters. A UPGMA phenogram was then generated to determine the relationships among Dipterocarpus species using 26 leaf and petiole characters. The most useful characters to delineate Dipterocarpus species are the presence of trichomes, the arrangement of vascular bundles (medullary and outer vascular bundles), areolation, fimbrial vein, and leaf size. Other characters viz., the laminar ratio, blade class, laminar shape, base shape, margin type, and intersecondary, and layers and shape of parenchyma and collenchyma cells were useful as unifying characters. Therefore, certain characters of the leaf architecture and petiole anatomy may be used as taxonomic markers to delineate and correlate the Dipterocarpus species in the Philippines particularly during the nonflowering phase of the species. However, further investigations using samples from the wild populations of the species and molecular techniques may be done to elucidate the taxonomic use of the characters presented in this study.
\end{abstract}

\section{Introduction}

Leaf characters are considered as important morphological features for taxonomic studies (Swaminathan et al., 2012). These include leaf architectural characters, venation patterns (Pulan and Buot, 2014), and petiole anatomical characters (Ruzi et al., 2009; Solereder, 1908). Although leaves are generally plastic, mostly to environmental conditions, and are sometimes neglected in taxonomy, the leaf architecture and venation patterns have long been considered useful for the taxonomy of different dicotyledonous families, including Scrophulariaceae (Verghese, 1969), Rubiaceae (Banaticla and Buot, 2004), Solanaceae (Inamdar and Murthy, 1978), Apocynaceae (Mohan and Inamdar, 1982), and even monocotyledonous families (Obico et al., 2007; Inamdar et al., 1983). Recently, the use of leaf architecture characters, such as variation in the $2^{\circ}$ vein angle divergence, was also considered a useful taxonomic tool in delineating Diplazium Swartz (Athyriaceae) species (Conda and Buot, 2018). Some of the leaf architectural characters such as leaf areolation, apex, shape, and size have already been described as good taxonomic markers for

*Corresponding author, email: bbpark@cnu.ac.kr

${ }^{1}$ Department of Environment and Forest Resources, College of Agriculture and Life Sciences, Chungnam National

University, Republic of Korea; bbpark@cnu.ac.kr

${ }^{2}$ Department of Forestry and Environmental Science, College of Agriculture, Southern Luzon State University, Lucban 4328, Quezon, Republic of the Philippines. dennispulan@ gmail.com

${ }^{3}$ Institute of Biological Sciences, College of Arts and Sciences, University of the Philippines Los Baños, College 4031, Laguna, Republic of the Philippines; inocencio.buot@upou.edu.ph 
the description and identification of Shorea species (Dipterocarpaceae) in the Philippines and eastern Himalayas (Khan et al., 2016; Pulan and Buot, 2014). In addition, Solereder (1908) reported that the petiole anatomy, particularly the arrangement and structure of vascular bundles in the petiole, is useful for the diagnostic of genera of the Dipterocarpaceae (Ruzi et al., 2009; Howard, 1974; Metcalfe, 1944). The taxonomic importance of the petiole anatomy in the genus Cinnamomum Blume (Lauraceae) was also described as useful in the species identification (Abeysinghe and Scharaschkin, 2019).

The present study deals with the leaf architecture and petiole anatomy of Philippine Dipterocarpus C.F. Gaertn., the third largest and most diverse among the six genera (others are Hopea Roxb., Parashorea Kurz, Shorea Roxb. Ex C.F. Gaertn., Vatica L.) of the family Dipterocarpaceae. Dipterocarpus genus is regarded as an ecologically and economically important group of timber trees (under the trade name "Keruing") in lowland rainforests in the Philippines with ten species in the country (Whitford, 1911). Dipterocarpus species are generally indigenous, with one endemic to the Philippines, but are also threatened (DAO 2017-11). They are perennial shade tolerant and evergreen trees, which can grow up to nearly $40 \mathrm{~m}$. Based on our field observation, the branching pattern of Dipterocarpus species is distinctly verticellate which conforms to Massart's architectural model (i.e., monopodial trunk and branches with axilliary positions of inflorescences). In terms of seedling architecture, Dipterocarpus follows the Durian type (cotyledons easily fall off and replaced immediately by early leaves, eophylls). The inflorescences of Dipterocarpus species are in short racemes, and their fruits have wings with five elongated sepals. Flowers of Dipterocarpus are bell-shaped and considerably larger than those of other genera. Generally, Dipterocarpaceae species have a unique flowering characteristic, i.e., irregular and no distinct flowering patterns (Burgess, 1972; Sasaki et al., 1979; Appanah, 1993; Sakai, 2002). Harrison et al. (2005) observed that Dipterocarpus species flowers supra-annually, predominantly during community-wide general flowering events, posing difficulty for species identification.

In view of the ecological and economic significance of Philippine Dipterocarpus species, it is crucial for forest managers to correctly identify the species in the genus for conservation purposes, especially in the absence of flowers. The reproductive morphology has long been considered very useful in taxonomy, but there are cases in which flowers and fruits are not available for study. The use of leaf architectural and petiole anatomical characters of Dipterocarpus may have promising relevance in the taxonomy of the genus. Therefore, the objective of this study was to investigate the leaf architecture and petiole anatomy of eight Dipterocarpus species growing in Mount Makiling Forest Reserve (MMFR) in the Philippines to delineate the species, especially during their non-flowering phase.

\section{Materials and Methods}

\section{Leaf architecture and morphology}

Mature and healthy leaves from the terminal part of the orthotropic branches were collected from two representative individuals of each Dipterocarpus species growing in Mount Makiling Forest Reserve (MMFR). These species are D. alatus Roxb. Ex G. Don, D. gracilis Blume, D. grandiflorus (Blanco) Blanco, D. hasseltii Blume, D. kerrii King, D. kunstleri King, D. philippinensis Foxw., and D. validus Blume (Fig. 1). A total of 80 leaf samples (8 species $\times 2$ individuals $\times 5$ leaves) were used in the leaf architecture and morphology study. Thereafter, leaf architectural characters (i.e., leaf shape, venation, margin, base, apex, area, areolation, blade class, organization, presence of trichomes, and other epidermal appendages/indumentum) were examined following the standard and tested procedures (Dilcher, 1974; Hickey, 1973). 
Petiole anatomy and leaf epidermis

A total of 40 cross-sections ( 8 species $\times 5$ sections) of young petiole and leaves were prepared by freehand technique following the procedure of Keating (2014). Cross-sections of petioles were obtained from the median point using a sharp blade. Samples were observed under a compound microscope (Euromex 0112987) and were analyzed based on the following characters: area $\left(\mu \mathrm{m}^{2}\right)$ and thickness $(\mu \mathrm{m})$ of vascular bundles, xylem and phloem, and the number of layers of parenchyma, collenchyma, and sclerenchyma cells using an image processing and analysis software (Image J. v. 1.5). The shape of the petiole and vascular bundles was also described.

To examine the stomatal apparatus, the same leaves were used and subjected to leaf epidermal impressions technique based on the modified procedure of Gitz and Baker (2009). The type, shape, and area $\left(\mu \mathrm{m}^{2}\right)$ of stomata were determined using the same image processing software (Image J. v. 1.5). In addition, the shape of the epidermal cells was examined and described.

\section{Statistical Analysis and UPGMA Phenogram}

Significant variations in terms of leaf area, epidermal cells, stomata, and thickness of xylem, phloem, parenchyma, and sclerenchyma across species were determined using ANOVA in R studio statistical software (v 3.4.1) at $\alpha=0.05$ confidence level.

To determine the relationships among the species in terms of characters examined, unweighted pair group method with arithmetic mean (UPGMA) phenogram was generated in PAST software (v. 3.14). A total of 26 leaf characters were considered for the construction of the phenogram. These characters were laminar ratio, blade class, laminar shape, areolation, base angle, apex shape, margin type, intersecondary veins, presence/absence of trichomes, thickness and number of layers of parenchyma, collenchyma, sclerenchyma cells, arrangement, shape, diversity, and position of medullary and outer/peripheral vascular bundles, the shape of petiole, presence/absence of parenchyma cells in the vascular bundles, the shape of epidermal cells, and type of stomata.

\section{Results and Discussion}

\section{Leaf architecture and morphology characteristics}

The leaves of eight Dipterocarpus species are simple in alternate to spiral phyllotaxy, with varying shapes (subcordate, ovate to lanceolate, and oblong) and with a texture of either glabrous or scabrous. Among the species, D. validus had the largest mature leaf with leaf area of $498 \mathrm{~cm}^{2}$, while the smallest leaf was $D$. hasseltii with $45 \mathrm{~cm}^{2}$ leaf area. The laminar ratio $(2: 1)$ was similar in all species, except in D. kunstleri (3:1). The leaf base is also variable - acute in D. grandiflorus, convex in $D$. hasseltii, $D$. kunstleri, and $D$. kerrii, cordate leaf base in $D$. alatus, rounded in $D$. gracilis, and obtuse in D. Validus (Fig. 1). The leaf apices of D. validus, D. kunstleri, D. kerrii, D. gracilis, $D$. philippinensis, and $D$. grandiflorus are acuminate to slightly caudate, while $D$. alatus and $D$. hasseltii have acute leaf apex (Fig. 2). In terms of leaf margin, D. hasseltii has revolute to erosed leaf margin, and this is distinctly different from that of the other species (i.e., entire). Further, only $D$. validus has fimbrial vein type of marginal venation out of the eight studied species (Fig. 4).

Areoles are the smallest areas of leaf tissues surrounded by veins. Paxillate areolation was observed in D. kunstleri, D. kerrii, D. gracilis, and D. hasseltii. The other species have welldeveloped areolation (Fig. 3).

The major venation pattern conformed to the pinnate type. The highest order found in Dipterocarpus species is third-degree. The primary $\left(1^{\circ}\right)$ vein is thickest in the leaf base and narrow toward the leaf apex. The secondary veins $\left(2^{\circ}\right.$ or the next smallest order of veins after the primary 
vein) are all weak brochidodromous, whose angle of divergence was similar in all studied species. In some cases, the upper secondary veins are more obtuse than the lower ones such as in $D$. philippinensis and D. grandiflorus. The thickness of these veins is smoothly increasing toward the base and the vein course is generally straight. Weak inter-secondary veins were found occasionally in the species of Dipterocarpus. Tertiary veins $\left(3^{0}\right)$ are all alternate percurrent, obtuse divergence angle, and all sinous vein path.

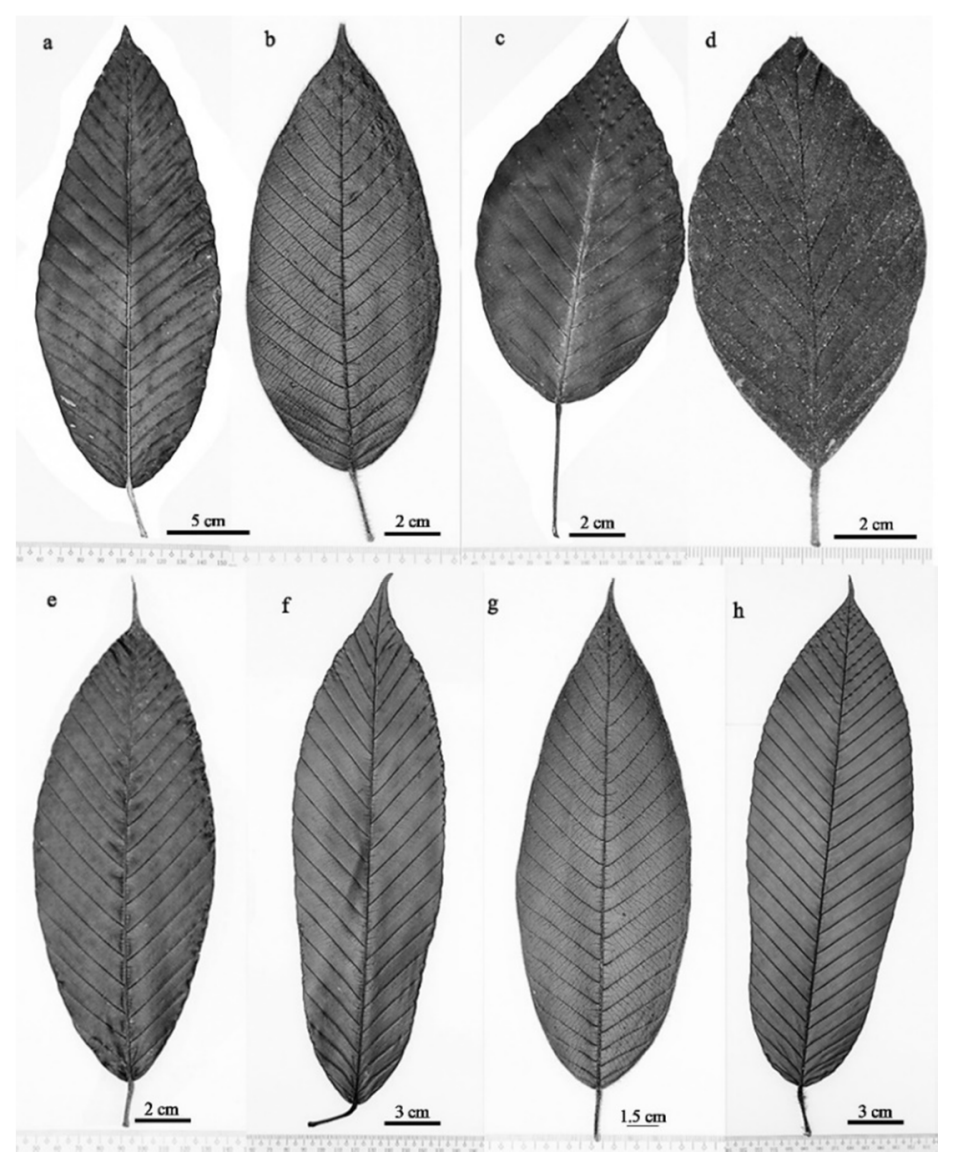

Fig. 1. Leaves of eight Dipterocarpus species used in this study. (a) D. alatus, (b) D. gracilis, (c) D. grandiflorus, (d) D. hasseltii, (e) D. kerrii, (f) D. kunstleri, (g) D. philippinensis, and (h) D. validus.

All species have geniculate (kneed) type of petiole but the length varied across species. The longest petiole (5-10 cm long) was observed in D. grandiflorus, while the shortest $(2-3 \mathrm{~cm})$ was observed in D. alatus and D. kunstleri. The other five species have petiole lengths ranging from 3$5 \mathrm{~cm}$ long.

\section{Petiole anatomy characteristics}

In this study, the petiole of the eight studied species is concave-convex (Fig. 5). The adaxial side is rounded and with prominent convexity on the abaxial surface. Except for D. grandiflorus, other species have flat-convex to concave-convex petiole, which is flat or slightly concave on the 
adaxial and rounded on the abaxial side (Fig. 5). The epidermis of all species is uniseriate. Their cortex is composed of 2-4 layers of polygonal angular collenchyma (adaxial surface) and isodiametric and thin-walled parenchyma cells (abaxial surface).

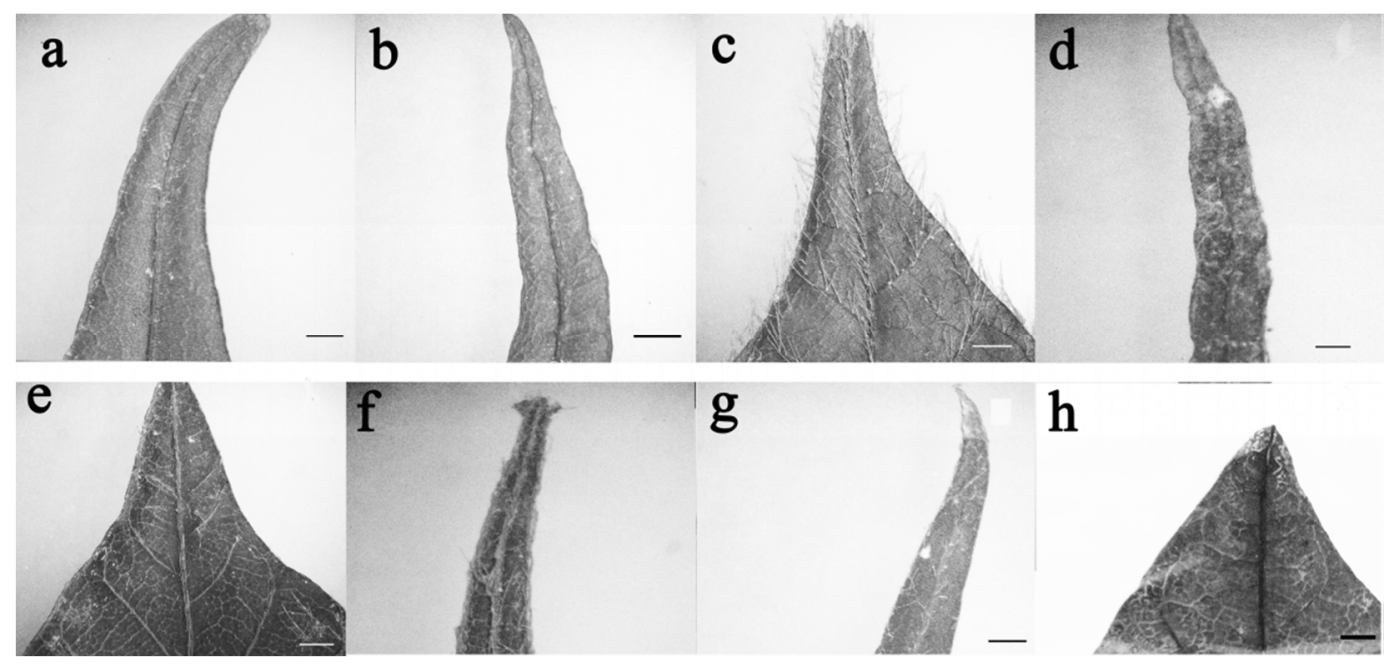

Fig. 2. Leaf apex of (a) D. validus, (b) D. kunstleri, (c) D. kerrii, (d) D. gracilis,(e) D. alatus, (f) D. philippinensis,(g) D. grandiflorus, and (h) D. hasseltii. (Bar $=10 \mathrm{~mm})$.

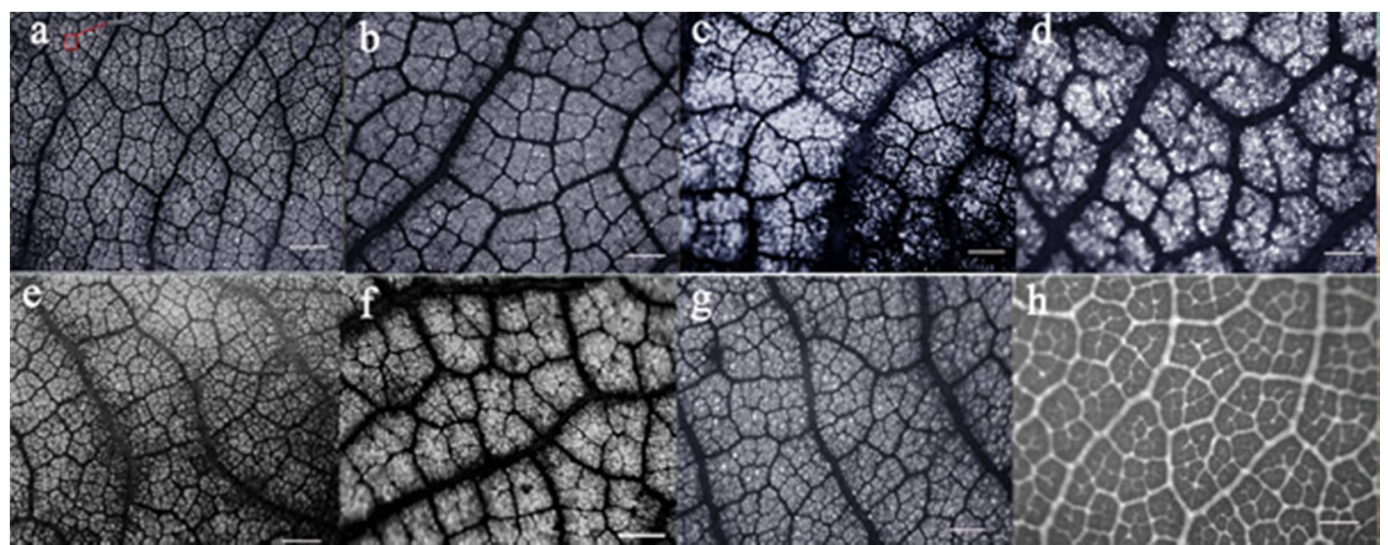

Fig. 3. Leaf areolation of (a) D. validus, (b) D. kunstleri,(c) D. kerrii, (d) D. gracilis,(e) D. alatus, (f) D. philippinensis, $(\mathrm{g})$ D. grandiflorus, and (h) D. hasseltii. $(\mathrm{Bar}=10 \mathrm{~mm})$.

All species have a collateral type of vascular bundles (Vbs) (Fig. 5). Four classifications of Vbs were determined in the studied Dipterocarpus species (Fig. 6). Class 1 includes D.gracilis, $D$. validus, and D. kunstleri. In this group, the petiole consists of medullary Vbs (closed system and circular) and outer/peripheral Vbs (closed with an interrupted O-shaped ring Vbs, Fig. 6a). Class 2 includes $D$. grandiflorus, which consists of medullary Vbs (closed system with an interrupted Oshaped ring of Vbs and a few clusters of Vbs in the middle) and outer/peripheral Vbs (closed system and continuous O-shaped ring of $\mathrm{Vbs}$, Fig. 6b). The third class includes $D$. hasseltii and $D$. kerrii. In this group, the medullary Vbs are opened system and U-shaped of several Vbs on abaxial 
side and the outer/peripheral Vbs are closed system with an interrupted O-shaped ring of Vbs (Fig. 6c). The last class includes $D$. alatus and D. philippinensis. It is characterized by having closed interrupted medullary Vbs that consists of U-shaped Vbs on abaxial side and separated Vbs on adaxial side and closed interrupted outer/peripheral vascular bundles (Fig. 6d). Shapes of Vbs of $D$. alatus, D. gracilis, and D. validus are lachrymiform (broad and round towards the abaxial surface). The D. hasseltii, D. kerrii, and D. kunstleri have round-shaped Vbs. Stellate and oblong Vbs were observed in $D$. grandiflorus and $D$. philippinensis, respectively.
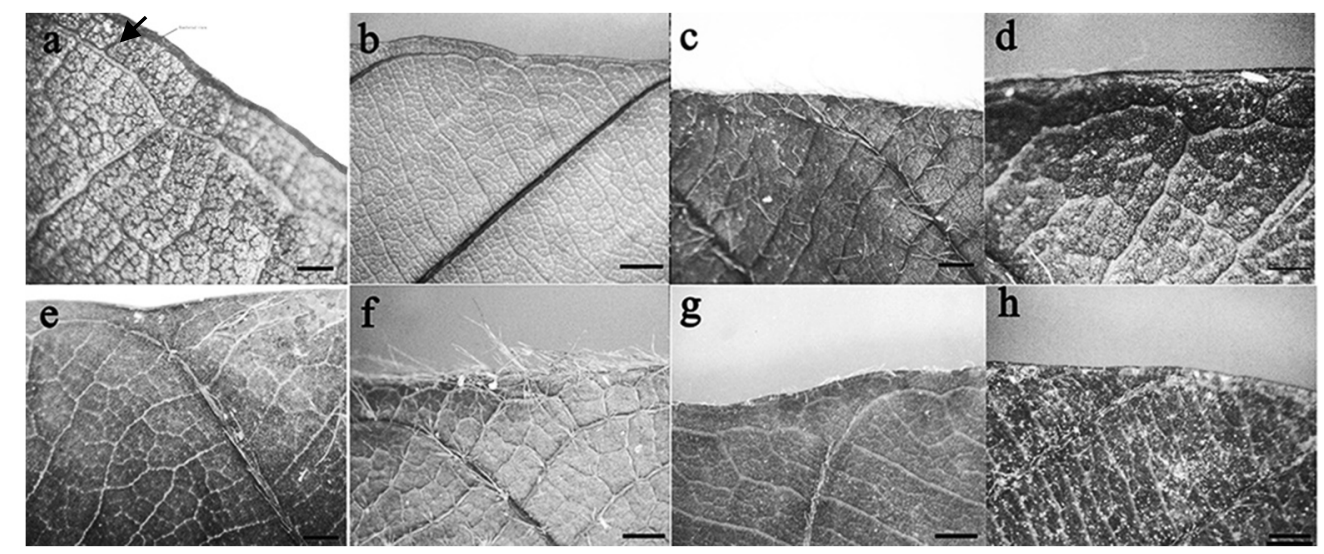

Fig. 4. Leaf margin of (a) D. validus, (b) D. kunstleri, (c) D. kerrii, (d) D. gracilis, (e) D. alatus, (f) D. philippinensis,(g) D. grandiflorus, and (h) D. hasseltii. The arrow denotes fimbrial vein. (Bar $=10 \mathrm{~mm})$.
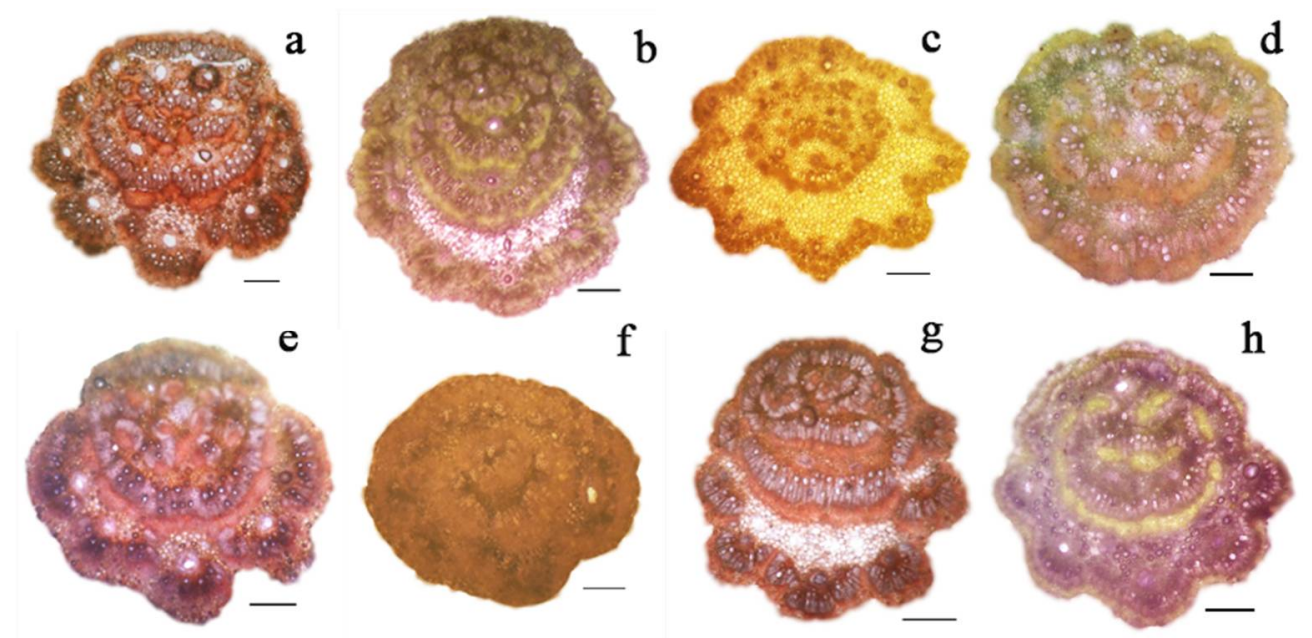

Fig. 5. Petiole anatomy showing the shape of vascular bundles of (a) D. alatus, (b) D. gracilis, (c) D. grandiflorus, (d) D. hasseltii, (e) D. kerrii, (f) D. kunstleri, (g) D. philippinensis, and (h). D. validus. $(\operatorname{Bar}=10 \mu \mathrm{m})$.

Inside the vascular bundles are 3-10 layers of round to isodiametric shaped parenchyma cells. These parenchyma cells were very prominent in D. gracilis (3-5 layers), D. grandiflorus (5-10 layers), and D. philippinensis (4-6 layers). Lastly, sparsely scattered sclerencyma cells were present around peripheral vascular bundles in all the studied Dipterocarpus species. 


\section{Stomatal and epidermal characteristics}

Six of the eight species have trichomes (i.e., conical, cylindrical, and peltate) (Fig. 7). The $D$. grandiflorus and $D$. kunstleri are the only two species that lack trichomes. The longest unicellular and cylindrical-conical trichomes were observed in D. validus $(10-28 \mathrm{~mm})$ followed by $D$. philippinensis $(10-15 \mathrm{~mm})$, D. gracilis $(8-10 \mathrm{~mm})$, D. kerrii $(2-8 \mathrm{~mm})$, and D. alatus $(0.5-2 \mathrm{~mm})$. Most of these trichomes are distributed on the surface of the petiole, leaf base, and along the midrib (both abaxial and adaxial sides of the leaf). Trichomes of $D$. philippinensis and D. gracilis can also be observed along the leaf margin. Lastly, multicellular peltate trichomes were observed in D. hasseltii (2-6 mm), which consists of a plate or shield-shaped cells attached to a stalk (Fig. 7 f).

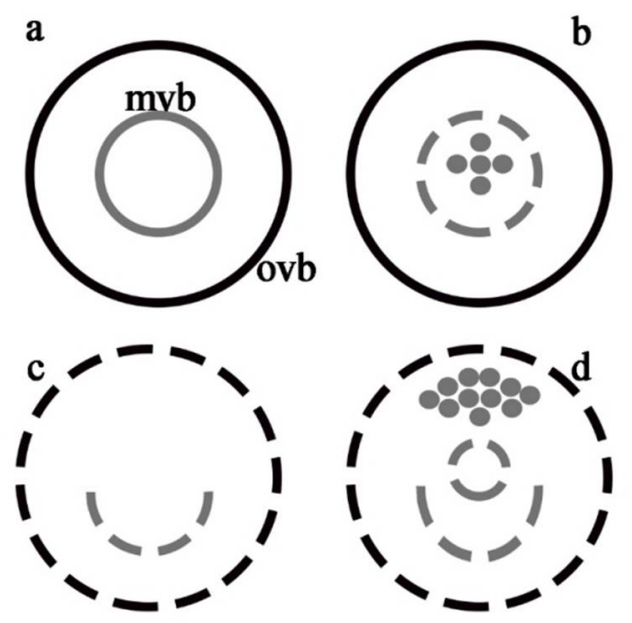

Fig. 6. Classifications of position and arrangement of medullary vascular bundles (mvb) and outer/peripheriral vascular bundles (ovb) observed in Dipterocarpus species showing (a) Class 1, (b) Class 2, (c) Class 3, and (d) Class 4.

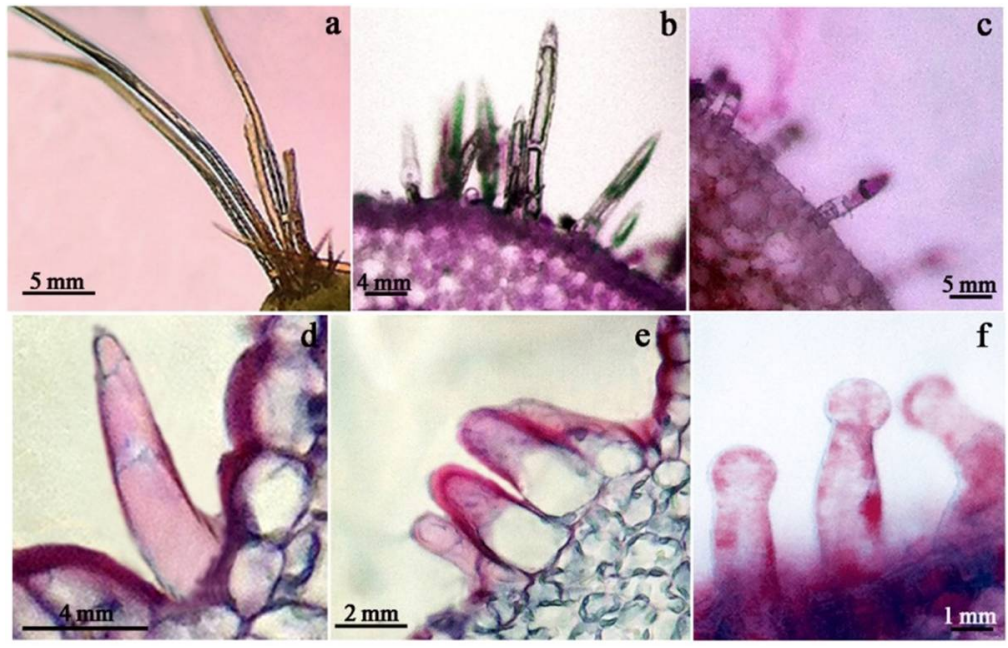

Fig. 7. Unicellular cylindrical-conical trichomes of (a) D. validus, (b) D. philippinensis, (c) D. gracilis, (d), D. kerrii, (e) D. alatus, and (f) D. hasseltii. 


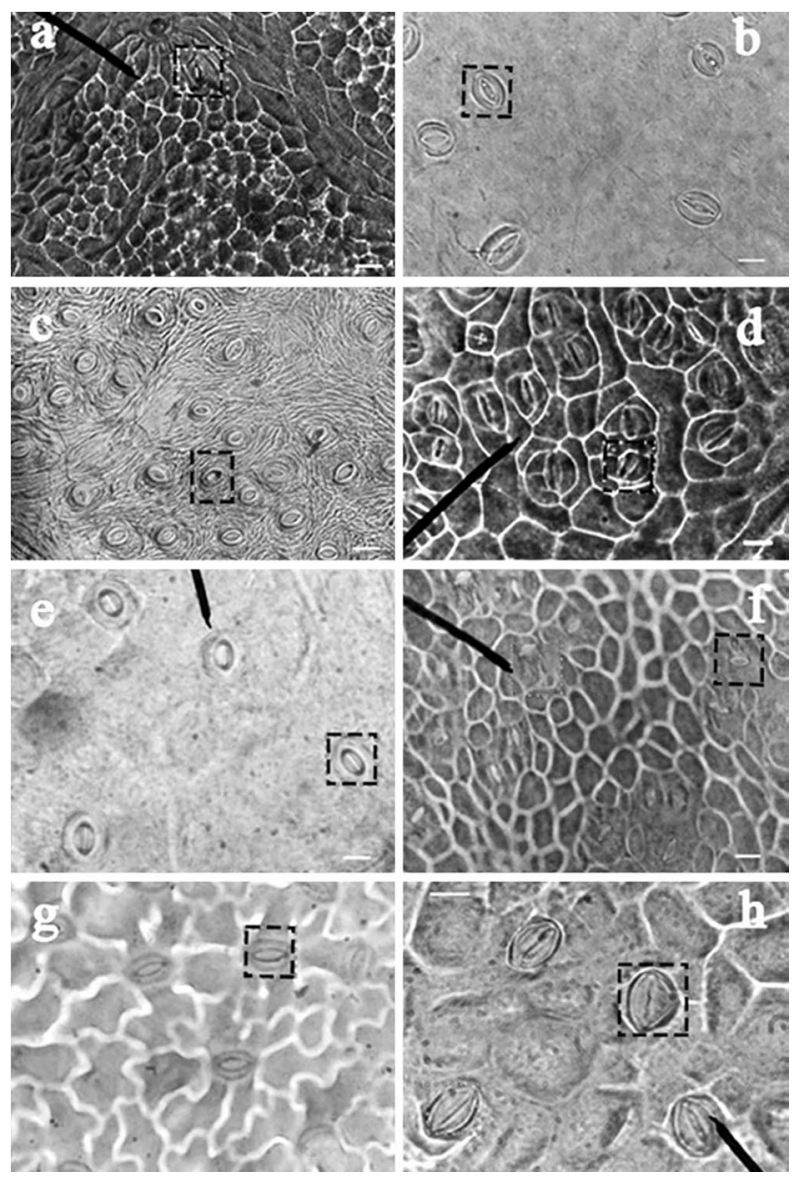

Fig. 8. Epidermal anatomy of eight Dipterocarpus species from MMFR showing the shape of epidermal cells and stomata. (a) D. alatus, (b) A. gracilis, (c) D. grandiflorus, (d) D. hasseltii, (e) D. kerrii, (f) D. kunstleri, (g) D. philippinensis, and (h) D. validus. The bar represents $10 \mu \mathrm{m}$.

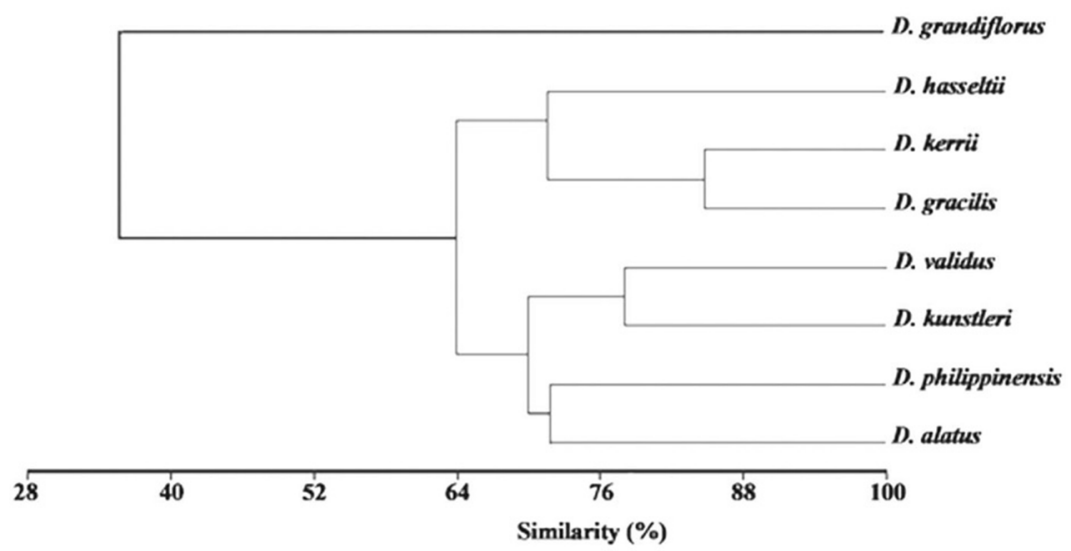

Fig. 9. UPGMA phenogram based on 26 leaf architectural and petiole anatomical characters of the eight Philippine Dipterocarpus species. 
The type and shape of stomata and epidermal cells were also variable across Dipterocarpus species (Fig. 8). All species are hypostomatic (limited to the abaxial surface). Four types of stomata were found, namely; paracytic or parallel celled (D. alatus and D. kunstleri), anomocytic (D. gracilis, D. validus, D. kerrii and D. grandiflorus), anisocytic or unequal celled (D. hasseltii), and hemiparacytic (D. philippinensis). Three of the eight species have irregular shape of epidermal cells, including D. gracilis, D. validus and D. kerrii. Two species (D. alatus and D. kunstleri) have polygonal to benzene-like ring shape of epidermal cells, while $D$. philippinensis, $D$. grandiflorus, and $D$. hasseltii have plicate, elongated, and pentagonal shapes, respectively.

\section{ANOVA and UPGMA phenogram}

Results of the ANOVA revealed that Philippine Dipterocarpus species are statistically variable in their leaf architecture and petiole anatomy. Significant ANOVA values at $\alpha=0.05$ ( $F$ value, $p$-value $)$ were re-coded in leaf area $(22.35,0.021)$, epidermal cell area $(92.96,0.021)$, stomata area $(47.92,0.021)$, vascular bundle area $(21.04,0.039)$, xylem conduits thickness $(9.76$, 0.017), phloem conduits thickness $(6.94,0.026)$, parenchyma cells thickness $(9.03,0.005)$, collenchyma cells thickness $(3.44,002)$, sclerenchyma cells thickness $(2.44,0.021)$, length of trichomes $(5.43,0.031)$, and petiole length $(3.94,0.027)$. However, this result was based on a limited number of samples.

Lastly, the variation in Dipterocarpus species was shown mainly in the UPGMA phenogram based on 26 leaf architectural and petiole anatomical characteristics (Fig. 9). This separated $D$. grandiflorus from the other species with a similarity of $35.69 \%$. Additional four clusters were observed: (1) D. gracilis and D. kerrii with similarity level of $84.84 \%$, (2) D. validus and D. kunstleri with 78. 05\%, (3) D. philippinensis and D. alatus with $71.80 \%$, and (4) D. hasseltii was separated from the other members of the genus with a similarity of $71.57 \%$.

\section{Distinctive leaf characters across species}

This paper reports for the first time on distinctive characters of leaf architecture and petiole anatomy of Philippine Dipterocarpus species. The phenogram showed that D. grandiflorus is distinctly separated from the other studied species, which may be attributed to the absence of trichomes and the presence of elongated epidermal cells. In addition, D. grandiflorus is the only species that belong to Class 2 vascular bundles. In this class, the petiole has closed medullary vascular bundles with an interrupted O-shaped ring of vascular bundles in the middle. Solereder (1908) reported that diversity in the position, shape, and distribution of medullary (center of the petiole) and peripheral vascular bundles are useful for the diagnosis of genera in the Dipterocarpaceae. The arrangement and structure of vascular bundles in petiole has also long been considered useful for classification (Ruzi et al., 2009; Metcalfe, 1944) and most useful at the genetic level of species identification (Howard 1974). Munawirah et al. (1991) also mentioned that the presence of medullary vascular bundles in the petiole of Dipterocarpaceae species can be used as a taxonomic character. In delimiting taxa, anatomical evidence has already been exploited in many higher plants, and petiole anatomy was one of the important biomarkers (Shahri et al., 2016; Ingole and Kaikade, 2015).

The phenogram also showed that $D$. hasseltii consists of leaf characters that significantly differed from the other species, which can be ascribed to its slightly revolute to erosed leaf margin type, peltate trichomes, and smallest leaf size. In addition, $D$. hasseltii is the only species that has anisocytic stomata (unequal celled) in combination with paracytic stomata. To our knowledge, no studies have yet been published on the plasticity of the leaf margin. It has been suggested that the use of leaf margin descriptors are useful in the automated leaf identification process (Cerutti et al., 2014). Khan et al. (2014) reported that stomata type was found not plastic to environmental 
changes (e.g., temperature gradient). This is despite the reports on the plasticity of other stomatal characteristics such as size and density to water and temperature manipulations (Fraser et al., 2008; Bañon et al., 2004). Thus, the type of stomata of D. hasseltii may also be used as a taxonomic character in addition to its leaf margin. However, further investigations using leaf samples from other habitat types are necessary to validate or strengthen the presumed taxonomic use of leaf margin and stomata type of $D$. hasseltii. Many studies have described the plasticity of leaf morphology and anatomy to water stress (Zhang et al., 2011), temperature gradient (Royer et al., 2009; Sack et al., 2006), and hydrostatic gradient (Cavaleri et al., 2010). Most of the leaf morphological characters that were found responsive to environmental factors are leaf shape (e.g., Maugarny-Calès and Laufs 2018), leaf venation (e.g., Zhang et al., 2018), and leaf area (e.g., Royer et al., 2008), which can influence the overall leaf morpho-anatomical structures, including leaf margin and stomata.

The similarity of $D$. gracilis and $D$. kerrii may be attributed to the presence of trichomes. All leaf architectural characters used in this study were found similar in D. gracilis and D. kerrii. These characters are laminar ratio (2:1), blade class (mesophyll), laminar shape (lanceolate), areolation (paxillate), base angle (acute), base shape (convex), apex shape (accuminate), margin type (entire), and inter-2 veins (absent). These two species are gregarious and both distributed on the islands of Luzon and Mindanao in the Philippines. Further, D. gracilis and D. kerrii are adapted to lateritic soils in seasonally dry lowland dipterocarp forests at 400-800 meters above sea level (Pelser et al., 2011). These habitat characteristics of the two species may be expressed in their petiole anatomical structure by the presence of multiple layers of parenchyma or storage cells in addition to having dense layers of trichomes. Generally, parenchyma cells are alive at maturity and function for storage and photosynthesis. Such thick parenchyma cells may suggest an adaptation of species to dry habitat conditions (Hernandez et al., 2016). Presumably, D. gracilis and D. kerrii have long acquired such characteristic (i.e., genetically inherent), enabling them to thrive in lateritic soils in seasonally dry lowland areas before they were planted outside their natural habitat. This is considering that the samples used in this study were collected from MMFR (i.e., outside the natural habitat of the studied species). However, the presence of thick strata of parenchyma cells inside the medullary and peripheral vascular bundles may only aid the correct identification of species of Dipterocarpus due to plasticity issues. Parenchyma cells are typical of many terrestrial plants; hence, the increased layers of the cells in the petiole may have only been due to the species adaptation to a new habitat. Recent studies have proven that the presence of parenchyma and collenchyma cells in plant tissues are merely influenced by the environment (Radice and Arena 2015; Guo et al., 2007). Hence, further investigations may be needed to validate whether the thick layers of parenchyma cells within the vascular bundles of $D$. gracilis and $D$. kerrii are genetically inherent or just a form of structural plasticity. This implies that only the presence of cylindrical trichomes may be considered as a good taxonomic character for $D$. gracilis and D. kerrii. Munawirah et al. (1991) mentioned that type of trichomes served as a useful character in the identification of Malaysian Dipterocarpaceae species. The presence of simple and unicellular trichomes has long been reported in the family Dipterocarpaceae (Noraini and Cutler 2009; Solereder 1908; Metcalfe and Chalk, 1950). In addition, many taxonomic and systematic uses of trichomes were cited in many studies of problematic genera and families, including Lamiaceae (Eiji and Salmaki 2015), Verbenaceae (Iroka et al., 2015), and Malvaceae (Celka et al., 2006).

The similarity of $D$. kunstleri and $D$. validus may be ascribed to their similarity in blade class (macrophyll), laminar shape (oblong), apex shape (acuminate), leaf margin type (erose to repand), and inter-2 veins (weak). Further, these two species have similar types of vascular bundles (i.e., Class 1, closed and circular medullary Vbs with an interrupted O-shaped ring and closed outer 
Vbs). D. kunstleri and D. validus are both gregarious and common in primary lowland forests in the Philippines.

Lastly, a good leaf character that can explain the similarity of D. alatus and D. philippinensis may include the type of petiole vascular bundle (opened system medullary vascular bundles with U-shaped bundles on abaxial side). Further, they have a similar laminar ratio (2:1), blade class (mesophyll), areolation (well-developed), leaf margin type (entire to erose), and inter-2 veins (weak). The clustering of $D$. alatus and D. philippinensis is expected because the latter has long been recorded as the synonyms of $D$. alatus which was first observed in Eastern India, Cambodia, Laos, Vietnamn, Thailand, and Malaysia (Smitinand et al., 1993). Natural populations of $D$. philippinensis can be found in primary mixed dipterocarp forest and seasonal dry areas in Abra, Nueva Viscaya, and Bataan (Pelser et al., 2011; Smitinand et al., 1993).

Another distinctive characters that were found useful as taxonomic characters are the areolation and leaf size. Many studies reported that these morpho-architectural characters are useful in identifying or delineating certain plant taxa (Pulan and Buot 2014; Celadiña et al., 2012; Laraño and Buot 2010). For example, leaf areolation has become one of the useful leaf morphological characters to explain the early evolution, diversification, and biogeographic history of orchid trees, Bauhinia L. (Lin et al., 2015). The presence of fimbrial vein was also found as a good distinguishing character for the species, which has long been used as one of the leaf architectural characters to determine the phylogenetic affinities of Nothofagus Blume leaf fossils (Jordan and Hill, 1999).

\section{Unifying leaf characters across species}

The present study also reports for the first time on the unifying features of the Philippine Dipterocarpus species. These features include: simple leaves, alternate to spiral phyllotaxy, pinnate $1^{\circ}$ vein, weak brochidodromous $2^{\circ}$ vein, sinuous $3^{\circ}$ vein course, symmetrical laminar symmetry, and marginal petiolar attachment, decreasing toward the base 2 vein spacing, vein angle variability that is all increasing basally, and alternate percurrent $4^{\circ}$ vein. Other characters such as the laminar ratio, blade class, laminar shape, base angle, base shape, margin type, and intersecondary veins were also useful as unifying characters for the genus. The pattern and composition of tissues of the characters such as the uniseriate epidermis, 1-2 layers of angular collenchyma cells and 3-5 layers polygonal parenchyma cells cortex, and a high number of vascular bundles were found nearly similar in all the studied species.

\section{Conclusions}

Correct identification of Dipterocarpus species is very important for their effective in-situ and ex-situ conservation. In the case of Dipterocarpus species in MFFR, D. alatus, D. gracilis, D. grandiflorus, D. hasseltii, D. kerrii, D. kunstleri, D. philippinensis, and D. validus were found different in terms of the structure of vascular bundles, type of stomata, and presence of trichomes, which are good taxonomic markers for the genus. The unifying features of the studied species were mostly leaf architectural characters. Therefore, during the non-flowering phase of the life cycle of Dipterocarpus species, these unifying and distinguishing diagnostic character states may be used as good taxonomic markers to delineate the Dipterocarpus species in the Philippines. However, further investigations using samples from the wild populations of the species and molecular techniques may be done to elucidate the taxonomic use of the characters presented in this study. 


\section{Acknowledgement}

The authors would like thank the Makiling Center for Mountain Ecosystems office for providing us the permit to collect leaf samples materials for the study.

\section{References}

Abeysinghe, P.D. and Scharaschkin, T. 2019. Taxonomic value of the petiole anatomy in the genus Cinnamomum (Lauraceae) found in Sri Lanka. Ruhuna J. Sci. 10: 1-17.

Appanah, S. 1993. Mass flowering of dipterocarp forests in the aseasonal tropics. J Biosci 18: 457-474.

Banaticla, M.C. and Buot, I.E. 2004. Leaf architecture of the Philippine Psychortia species, (Rubiaceae). Philippine Sci. 41: 74-90.

Bañon, S., Fernandez, J., Franco, J., Torrecillas, A., Alarcón, J. and Sánchez-Blanco, M. 2004. Effects of water stress and night temperature preconditioning on water relations and morphological and anatomical changes of Lotus creticus plants. Sci. Hortic. 101: 333-342.

Burgess, P.F. 1972. Studies on the regeneration of the hill forests of the Malay Peninsula: the phenology of dipterocarps. Malaysian For. 35: 103-122.

Cavaleri, M.A., Oberbauer, S.F., Clark, D.B., Clark, D.A. and Ryan, M.G. 2010. Height is more important than light in determining leaf morphology in a tropical forest. Ecology 91: 1730-1739.

Celka, Z., Szkudlarz, P. and Biereznoj, U. 2006. Morphological variation of hairs in Malva alcea L. (Malvaceae). Biodiv. Res. Conserv. 3: 258-261.

Celadiña, D.A., Buot, I.E., Madulid, D.A., Evangelista, T.T. and Tandang, D.N. 2012. Leaf architecture of selected Philippine Cinnamomum Schaeff. (Lauraceae) species. The Thailand Natural History Museum Journal 6: 89-111.

Cerutti, G., Tougne, L., Coquin, D. and Vacavant, A. 2014. Leaf margins as sequences: A structural approach to leaf identification. Pattern Recognit Lett. 49: 177-184.

Conda, J.M. and Buot, J.I. 2018. Species delineation of the genus Diplazium Swartz (Athyriaceae) using leaf architecture characters. Bangladesh J. Plant Taxon. 25: 123-133.

Department Administrative Order (DAO) No. 2017-11. 2017. Updated National List of Threatened Philippine Plants and their Categories. Department of Environment and Natural Resources, Quezon City.

Dilcher, D. 1974. Approaches to the identification of angiosperm leaf remains. Bot. Rev. 40: 1-156.

Eiji, S. and Salmaki. Y. 2015. Evolution of trichomes and its systematic significance in Salvia (Mentheae; Nepetoideae; Lamiaceae). Bot. J. Linn. Soc. 180: 241-257.

Fraser, L.H., Greenall, A., Carlyle, C., Turkington, R. and Friedman, C.R. 2008. Adaptive phenotypic plasticity of Pseudoroegneria spicata: Response of stomatal density, leaf area and biomass to changes in water supply and increased temperature. Ann. Bot. 103: 769-775.

Gitz, D.C. and Baker, J.T. 2009. Methods for creating stomatal impressions directly onto archivable slides. Agron. J. 101: 232.

Guo, W.H., Li, B., Zhang, X.S. and Wang, R. 2007. Architectural plasticity and growth responses of Hippophae rhamnoides and Caragana intermedia seedlings to simulated water stress. J. Arid. Environ. 69:385-99.

Harrison, R.D., Nagamitsui, T., Momose, K. and Inoue, T. 2005. Flowering Phenology and Pollination of Dipterocarpus (Dipterocarpaceae) in Borneo. Malayan Nat. J. 57: 67-80.

Hernandez, J.O., Malabrigo, Jr P.L., Quimado, M.O., Maldia, L.S.J. and Fernando, E.S. 2016. Xerophytic characteristics of Tectona philippinensis Benth. \& Hook.f. Philipp. J. 145: 259-269.

Hickey, L.J. 1973. Classification of the architecture of dicotyledonous leaves. Am. J. Bot 60:17-33.

Howard, R.A. 1974. The stem-node-leaf continuum of the dicotyledoneae. J. Arn. Arbor. 55: 125-173.

Inamdar, J.A., Shenoy, K.N. and Rao, N.V.1983. Leaf architecture of some monocotyledons with reticulate venation. Ann. Bot. 52: 725-735.

Inamdar, J.A. and Murthy, G.S.R. 1978. Leaf architecture in some Solanaceae. Flora 167: 265-272. 
Ingole, S.N. and Kaikade, R.S. 2015. Study of petiolar anatomy of some medicinal plants mentioned in the Atharvaveda. Int. J. Res Stud. Biosci. 3: 103-106.

Iroka, C., Okeke, C., Izundu, A., Okereke, N. and Nyanayo, B. 2015. Taxonomic significance of morphological characters in the species of Stachytarpheta found in Awka, Nigeria. IJPSS 8: 1-6.

Jordan, G.J. and Hill, R.S. 1999. The phylogenetic affinities of Nothofagus (Nothofagaceae) leaf fossils based on combined molecular and morphological data. Int J Plant Sci 160: 1177-1188.

Keating, R.C. 2014. Preparing plant tissues for light microscopic study: a compendium of simple techniques. Missouri Botanical Garden Press: St. Louis, MO, USA.

Khan, M. A., Spicer, R. A., Spicer, T. E. and Bera, S. 2016. Occurrence of Shorea Roxburgh ex C. F. Gaertner (Dipterocarpaceae) in the Neogene Siwalik forests of eastern Himalaya and its biogeography during the Cenozoic of Southeast Asia. Rev Palaeobot. Palynol. 233: 236-254.

Khan, F., Yousaf , Z., Ahmed, H., Arif, A., Rehman, H., Younas, A. and Raiz, N. 2014. Stomatal patterning: an important taxonomic tool for systematical studies of tree species of angiosperm. Ann. Res. Rev. 4 : 4034-4053.

Laraño, A. and Buot, I.E. 2010. Leaf architecture of selected species of Malvaceae sensu APG and its taxonomic significance. Philipp. J. Syst. Biol. 4: 21-51.

Lin, Y., Wong, W.O., Shi, G., Shen, S. and Li, Z. 2015. Bilobate leaves of Bauhinia (Leguminosae, Caesalpinioideae, Cercideae) from the middle Miocene of Fujian Province, southeastern China and their biogeographic implications. BMC Evol. Biol. 15: 252.

Maugarny-Calès, A. and Laufs, P. 2018. Getting leaves into shape: A molecular, cellular, environmental and evolutionary view. Development 145.

Metcalfe, C.R. and Chalk, L. 1950. Anatomy of the Dicotyledons: Leaves, Stem and Wood in Relation to Taxonomy with Notes on Economic Uses. Volume I. The Clarendon Press. Oxford, England.

Metcalfe, C.R. 1944. On the taxonomic value of the anatomical structure of the vegetative organs of the dicotyledons. Proc. Linn. Soc. 155: 210-235.

Mohan, J.S. and Inamdar, J.A. 1982. Leaf architecture in Apocynaceae. P. Indian As. Sci. 91: 189-200.

Munawirah P., Khatijah H. and Latiff, A. 1991. Anatomi petiol beberapa spesies daripada famili Dipterocarpaceae Malaysia. Prosiding Prioriti Penyelidikan 83: 610-617.

Noraini, T. and Cutler, D.F. 2009. Leaf anatomical and micromorphological characters of some Malaysian Parashorea (Dipterocarpaceae). J. Trop. For. Sci. 21: 1-7.

Obico, J.J., Bagay, K.C., Asencion, A.S. and Medecillo, M. 2007. Comparative study of the leaf morphology of Epipremnum Schott and RhaphidophoraHassk. (Araceae) in the Philippines. Philipp. J. Syst. Biol. 1: $15-25$.

Pelser, P.B., Barcelona, J.F. and Nickrent, D.L. (eds.). 2011. Co's Digital Flora of the Philippines. <www.philippineplants.org>. Retrieved on 11 November 2019.

Pulan, D.E. and Buot, I.E. 2014. Leaf architecture of Philippine Shorea species (Dipterocarpaceae). Int. J. Biol. Sci. 3: 19-26.

Radice, S. and Arena, M.E. 2015. Environmental effect on the leaf morphology and anatomy of Berberis microphylla G. Forst. Int. J. Plant Biol. 6.

Royer, D.L., Mcelwain, J.C., Adams, J.M. and Wilf, P. 2008. Sensitivity of leaf size and shape to climate within Acer rubrum and Quercus kelloggii. New Phytol. 179: 808-817.

Royer, D.L., Meyerson, L.A., Robertson, K.M. and Adams, J.M. 2009. Phenotypic Plasticity of Leaf Shape along a Temperature Gradient in Acer rubrum. PLOS ONE 4. doi:10.1371/journal.pone.0007653

Ruzi, A.R., Hussin, K. and Noraini, T. 2009. Systematic significance of the petiole vascular bundles types in Dipterocarpus Gaertn. f. (Dipterocarpaceae). Malays Appl. Biol. 38: 11-16.

Sack, L., Melcher, P.J., Liu, W.H., Middleton, E. and Pardee, T. 2006. How strong is intracanopy leaf plasticity in temperate deciduous trees? Am. J. Bot. 93: 829-839.

Sakai, S. 2002. General flowering in lowland mixed dipterocarps. Biol. J. Linn. Soc. 75: 233-247. 
Sasaki, S., Tan, C.H. and Zulfatah, H. 1979. Some observations on unusual flowering and fruiting of dipterocarps. Malaysian For. 42: 38-45.

Shahri, S. M., Jafari, A. and Mahmoodzadeh, H. 2016. Comparative anatomical studies on petioles of Nepeta L. species (Lamiaceae) in NE Iran. Adv. Stud. Biol. 8: 119-126.

Solereder, H. 1908. Systematic Anatomy of the Dicotyledons: A Handbook for Laboratories of Pure and Applied Botany. The Clarendon Press, Oxford, England.

Smitinand, T., Tompsett, P.B. and Cheek, M. 1993. A New Synonym and a Range Extension for Dipterocarpus alatus. Kew Bull. 48: 397.

Swaminathan, C., Vijendra, Rao., R. and Shashikala, S. 2012. Preliminary Evaluation of Variations in Anatomical Properties of Melia dubia Cav. Wood. Int. J. Biol. Sci. 1: 1-6.

Verghese, T.M. 1969. A Contribution to the Foliar Venation of Scrophulariaceae. In: Recent Advances in Anatomy of Tropical Seed Plants. Hindustan Pub. Corp. Choudhury, K.A., Delhi, pp. 253-266.

Whitford, H.N. 1911. The Forests of the Philippines. Part 1, Forest Types and Products. Philippine Bureau of Forestry Bulletin No. 10. Bureau of Printing, Manila, pp. 94.

Zhang, L., Yang J., Huang, Y., Jia, Z. and Fang, Y. 2018. Leaf venation variation and phenotypic plasticity in response to environmental heterogeneity in Parrotia subaequalis (H. T. Chang) R. M. Hao et H. T. Wei, an endemic and endangered tree species from China. Forests 9: 247.

Zhang, Y., Equiza, M.A., Zheng, Q. and Tyree, M.T. 2011. Factors controlling plasticity of leaf morphology in Robinia pseudoacacia: III. biophysical constraints on leaf expansion under long-term water stress. Physiol. Plant 143: 367-374.

(Manuscript received on 07 November 2019; revised on 20 April 2020) 